PAWEŁ BIELICKI, PhD, Scholar

Pilecki Institute

Warsaw, Republic of Poland

bielicki11@gmail.com

UDK 327(497.1:5-15)"1970/1980"(093.2)

327(497.1)"1970/1980"(093.2)

originalan naučni rad / original scientific paper

primljeno / received: 26. 5. 2020.

prihvaćeno / accepted: 19. 5. 2021.

https://doi.org/10.29362/ist20veka.2021.2.bie.397-414

\title{
THE MIDDLE EAST IN YUGOSLAVIA'S FOREIGN POLICY STRATEGY IN THE 1970s
}

ABSTRACT: The article concerns the importance of the Middle East in Yugoslavia's foreign policy strategy in the years 1970-1980. The text is an introduction to in-depth research on subject matter not sufficiently developed by previous research and was written based on available documents of the US State Department, the Wilson Center Digital Archive, and the resources of the library of US President Gerald Ford. Additionally, I used available international scientific periodicals in English, source literature in English. Serbian, and Polish, as well as memoirs of the most important global political figures of that time, including Egyptian President Anwar Al-Sadat and Mohammad Reza Pahlavi, the last Shah of Iran.

KEYWORDS: Middle East, Egypt, Israel, Yugoslavia, USSR, United States

\section{Introduction}

The period of relative relaxation in international affairs in the 1970s also meant changes in relations between some state entities that had previously maintained close relations. One such example was the relations between Yugoslavia and the Middle Eastern countries in the years between 1970 and 1980. The purpose of my article is to introduce the importance of the Middle East region in Belgrade's foreign political activities in the above-mentioned decade from the death of Egyptian President Gamal Abdel Nasser in September of 1970 to the death of the Yugoslav leader Josip-Broz Tito in May of 1980. The basic assumption that I adopted is to indicate that Yugoslav diplomacy considered the Arab world as an important region for the activity of the Non-Aligned Movement, which was supposed to constitute a "third force" in international political relations, independent of the United States and the Soviet Union. I will focus on Yugoslav President Josip Broz-Tito's stance regarding the Yom Kippur War and the peace agreement between Israel and Egypt concluded at Camp David in March of 1979. I intend to raise the issue of Yugoslavia's decreasing im- 
portance in the Arab world in the second half of the decade due to the growing economic and ethnic difficulties in that Balkan country.

It will also be important to describe the position of Yugoslavia regarding the changes taking place in Iran after the Islamic revolution that took place there. It will be necessary to ask some research questions: what were the relations between Yugoslavia and the Arab countries in the early 1970s? What was the position of Yugoslav diplomacy on the Yom Kippur war? What were the relations between Belgrade and Tel-Aviv? What was Tito's view of the peace agreement between Israel and Egypt? What were the consequences of the Islamic revolution in Iran for Yugoslavia's foreign policy? At the beginning, I would like to discuss the relations between Yugoslavia and the Arab world in the early 1970s.

\section{Relations between Yugoslavia and the Middle East in 1970-1973. An Attempt to Redefine Cooperation}

In the early 1970s, relations between Yugoslavia and Arab countries were still lively. Taking over the central stage in the Non-Aligned Movement after the September 1970 death of Gamal Abdel Nasser who had ruled Egypt since 1954, Tito began to assert his political position in the region even more clearly than before. The consequences of the Six-Day War between Israel and the Arab countries in June of 1967, during which relations between Egypt and the Soviet Union had strengthened, also contributed to Yugoslavia's growing importance in the region. During the war, the Yugoslav leader strongly supported the Arab side, which he expressed by traveling to Moscow and other locations to meet with the Warsaw Block leadership at the height of the conflict. ${ }^{1}$ One of the outcomes was the decision to sever diplomatic ties with Israel. ${ }^{2}$ Such siding with the East exposed him to criticism from his closest associates, including Lazar Koliševski and Edvard Kardelj, but he stayed on that course. Arguing that the West did not support the non-aligned countries sufficiently, ${ }^{3}$ Tito had since sought to strengthen relations with the Middle East, hoping to build a counterweight to contacts with both superpowers, which he perceived as a threat to his country's sovereignty. However, since the end of 1970, the first differences in relations between Belgrade and the Arab world began to appear, especially in relations with Egypt. They were noteworthy because Cairo was recognized as the leader of the Arab coalition against Isra-

\footnotetext{
${ }^{1}$ Transcript of one such meeting of the communist leadership and Tito in Budapest in July of 1967 is excerpted by the Wilson Center Digital Archive. https://digitalarchive.wilsoncenter.org/ document/113622 (accessed March 13, 2021). Translated in Serbian in: Vladimir Petrović, Titova lična diplomatija. Studije i dokumentarni prilozi (Beograd: Institut za savremenu istoriju, 2010), 238-244.

2 Aleksandar Lebl, „Prekid diplomatskih odnosa SFRJ - Izrael 1967. godine”, Tokovi istorije, br. $1-4,(2001), 39-75$.

${ }^{3}$ Michał Zacharias, Komunizm, federacja, nacjonalizmy. System władzy w Jugosławii w latach 1943-1991, (Warsaw: Neriton Publishing House, Institute of History of the Polish Academy of Sciences (PAN), 2004), 273.
} 
el. It seems that differences began to appear directly after the death of Nasser, who was Tito's greatest ally in the Non-Aligned Movement. Due to US President Richard Nixon's ongoing visit to Belgrade in September of 1970, the Yugoslav leader did not come to Egypt for the funeral of Nasser, which surprised the new authorities in Cairo. The new president of Egypt, Anwar Sadat, wrote years later that the Egyptian Government and himself personally were unpleasantly surprised by Tito's absence, all the more so because Nasser, throughout his life, had admired Tito's active work on the international arena and expressed his appreciation for the long struggle to bring "happiness" and freedom to his people. ${ }^{4}$ Despite the initial tensions between the two countries, both sides realized that cooperation between Yugoslavia and Egypt was necessary, as demonstrated by Tito's visit to Egypt in February of 1971. During this visit, Sadat emphasized that the chairman of the League of Communists of Yugoslavia had supported Egypt significantly from the very beginning of the fight against Israel. ${ }^{5}$ Despite official declarations of friendship, for the first two years of Sadat's rule, relations between the two countries did not approach the level from the time of Nasser. ${ }^{6}$ Tito himself assessed Nasser's successor favorably, as evidenced by his words during his Washington visit in September of 1971, when, in response to Nixon's question about Sadat's character, he said he was more dynamic than his predecessor and his popularity among Egyptian society was growing. However, the Yugoslav leader pointed out that he did not know if this could be a permanent trend. ${ }^{7}$

The intensification of relations between Yugoslavia and the Middle East was also caused by the Vietnam War and the sharp criticism of the global activity of the United States in the Middle East. At the same time, Tito "forgot" that when the period of détente began it was the Soviet Union that gained increasing influence in the Arab world, an example of which was, among others, the military coup in Syria that brought to power Hafez Al-Assad, who had always been a staunch supporter of good relations with the Kremlin, or the growing influence in Iraq, where President Ahmad Hasan Al-Bakr and his deputy Saddam Hussein sought to improve contacts with Moscow. During this time, the Kremlin was also gaining prominence among the representatives of the Palestinian movement, as it financed the Palestine Liberation Organization and the terrorists that closely cooperated with it who were centered around, among others, the Popular Front for the Liberation of Palestine and the Black September Organi-

\footnotetext{
${ }^{4}$ Anwar Sadat, Nasser's Death and my Relations with Tito, https://anwarsadat.org/site/project $\mathrm{img} /$ book/4889.pdf, 3 (accessed April 11, 2020).

${ }^{5}$ Speech by President Anwar El-Sadat at the banquet given in honor of Yugoslav President Josip Broz Tito February 14, 1971, https://sadat.umd.edu/sites/sadat.umd.edu/files/Speech\%20at\% 20a\%20Banquet\%20Honoring\%20Yugoslav\%20President\%20Josip\%20Broz\%20Tito.pdf, 3-4, (accessed April 14, 2020).

6 Alvin Rubinstein, "The Evolution of Yugoslavia's Mediterranean Policy", International Journal, vol. 27, no. 4, (Autumn 1972), 541.

${ }^{7}$ Washington, 28 October 1971, Memorandum for the President's File, https://history.state.gov/ historicaldocuments/frus1969-76v29/d232 (accessed April 25, 2020).
} 
zation, which was responsible for the assassination of Israeli athletes during the Olympic Games in Munich in August 1972.8

Other Arab leaders, including Iran's Shah Mohammad Reza Pahlavi, observed with concern the rise of the Soviet position in this area. One should agree with Arthur Rubinstein, according to whom Tito ignored some representatives of Arab countries who expressed their misgivings regarding the Soviet Union's increasing influence in the Middle East, while he mainly criticized US activity in the region. ${ }^{9}$ Henry Kissinger also confirms his thesis about Tito's uncritical attitude toward the Arab countries, signaling in a letter of September 1971 to Nixon that Tito had been criticizing US policy toward the Arab countries for years as being pro-Israeli, anti-Arab, and "capitalist" motivated. Kissinger advised Nixon not to succumb to the stance of the Yugoslav president. ${ }^{10}$ On the other hand, Tito's close party associates recognized that the excessive concentration of Soviet troops in the Middle East could weaken Yugoslavia's position in that region. Mirko Tepavac, then minister of foreign affairs, noted that thanks to Soviet assistance, the Arabs were becoming stronger, which led to an increasing Soviet presence in the Middle East. According to him, this state of affairs could lead to a reduction of Yugoslavia's role in the Arab world. He said that Soviet politicians had an easier situation because the Arabs were completely helpless without Soviet support and protection. ${ }^{11}$

Moreover, it would be reasonable to suppose that the Yugoslav leader perceived the Middle East crisis as a threat to the situation in Yugoslavia and to his personal power in the country. In October of 1971, he stated that since the problems of the Middle East could not be resolved, the tension was spreading throughout the Mediterranean and its effects were also felt in the Balkans. According to Tito, the protracted crisis in the Middle East was causing deep concern among the European countries because their geostrategic and economic connections with the Middle East were closely related to their security. ${ }^{12}$ Additionally, Foreign Minister Tepavac thought that the situation in the Middle East was worrying also because of Yugoslavia's particular interests, because the military and political space of the Middle East was expanding to the entire Mediterranean and the part of Europe where his country was located. ${ }^{13}$ In the materials prepared for Tito in March of 1972, before meeting with Sadat, it can be

\footnotetext{
${ }^{8}$ Franciszek Bernaś, Mrok i mgła. Z dziejów KGB (Warszawa: ETNOS, 1997), 567-568.

${ }^{9}$ A. Rubinstein, The Evolution of Yugoslavia's Mediterranean Policy, 543.

${ }^{10}$ Josip Mocnik, United States-Yugoslav Relations, 1961-80: The Twilight of Tito's Era and the Role of Ambassadorial Diplomacy in the Making of America's Yugoslav Policy, Ohio 2008, https://etd.ohiolink.edu/!etd.send_file\%3Faccession\%3Dbgsu1206322169\%26disposition\%3Di nline, 123 (accessed April 16, 2020).

${ }^{11}$ October 5, 1970, Report on the talks between Henry Kissinger and Mirko Tepavac held on an airplane en route from Zagreb. https://digitalarchive.wilsoncenter.org/document/110827.pdf $? \mathrm{v}=\mathrm{c} 31782 \mathrm{af} 4 \mathrm{fe} 95 \mathrm{bc} 1 \mathrm{f} 2 \mathrm{~b} 9314 \mathrm{a} 9 \mathrm{fd} 2 \mathrm{e} 684,3$, (accessed April 24, 2020).

${ }^{12}$ A. Rubinstein, The Evolution of Yugoslavia's Mediterranean Policy, 542.

${ }^{13}$ October 5, 1970, Report on the talks between Henry Kissinger and Mirko Tepavac held on an airplane en route from Zagreb. https://digitalarchive.wilsoncenter.org/document/110827. pdf? $v=$ c31782af4fe95bc1f2b9314a9fd2e684, p. 3, op. cit., (accessed April 24, 2020).
} 
read that the continued Middle East crisis affected the entire Mediterranean, where both the United States and the USSR had significant long-term and conflicting interests. ${ }^{14}$ Therefore, Tito postulated that stopping the conflict would necessitate the direct involvement of the United States and the USSR. However, he noted, not without reason that it was in the best interests of both Moscow and Washington to maintain the conflict because their geopolitical interests were not jeopardized. The Yugoslav president noticed that it was also in the best interests of both superpowers to treat the Arabs as second-class citizens because they did not represent a power capable of forcing Israel to withdraw from the occupied territories by political or military means. ${ }^{15}$

Tito's anxiety regarding the situation in the Middle East had been growing since the beginning of 1973. While reporting to Leonid Brezhnev, the secretary general of the Central Committee of the CPSU in January of 1973 about his conversation with Sadat, Tito emphasized that the situation in the region was becoming more difficult because of Israel's reluctance to fulfill its obligations under the UN Security Council Resolution of 1967. According to Tito, Israel's aggressive action against Syria, Lebanon, and the Arabs in Palestine was posing a threat not only to the independence of the Middle Eastern nations, but also to the security of the Mediterranean countries and the stability of world peace. He even stated that if the situation continued, developments in the Middle East could lead to a further dangerous escalation of the conflict, leading to instability in the Mediterranean region. ${ }^{16}$ Referring to the above, he further maintained that the Arab Republic of Egypt could not cross a certain line and was determined, despite internal difficulties, to reject everything that was against the sovereignty and vital interests of Egypt and the other Arab countries. In support of Sadat's arguments, he confirmed that Yugoslavia was prepared to continue all possible efforts to find a political solution to the crisis in the Middle East. ${ }^{17}$ The Yugoslav leader's stance was implemented during the next Israeli-Arab war.

\section{Yom Kippur War and its Implications for Yugoslavia's Foreign Policy}

This article also looks at Yugoslavia's role in the Yom Kippur War in October of 1973. It is extremely important to say that in the face of improving relations with the Soviet Union in the early 70s, Tito consistently took the side of the Arab countries. This was not only associated with the US intervention in Vietnam but also the growing criticism of Western media regarding the authoritarian political system in Yugoslavia. Tito's failure to provide information for

\footnotetext{
${ }^{14}$ March 3, 1972, Briefing Book Prepared for Josif Tito on the Upcoming Visit of the President of UAR Anwar El Sadat to Yugoslavia, https://digitalarchive.wilsoncenter.org/document/ 113625.pdf? $\mathrm{v}=097 \mathrm{fe} 4 \mathrm{ecfbbefc145c59f67a615fffac,} \mathrm{p.} \mathrm{7,} \mathrm{(accessed} \mathrm{April} \mathrm{20,} \mathrm{2020).}$

${ }^{15}$ Ibid., 8.

16 January 18, 1973, Message from Josip Tito to Leonid Brezhnev, https://digitalarchive.wilson center.org/document/113624.pdf? $\mathrm{v}=\mathrm{ac} 1887587 \mathrm{fd} 90 \mathrm{~d} 1299 \mathrm{fc} 196553896 \mathrm{f6e}, \quad$ p. 1, (accessed April 25, 2020).

${ }^{17}$ Ibid., 2-3.
} 
the Western democracies regarding what Sadat said in January of 1973 - when, during a meeting with Tito, he warned that Egypt was prepared to fight with Israel the most ferocious battle in history, even more brutal than the Vietnam War - may be considered as proof of the Yugoslav leader's total support for the Arab countries. ${ }^{18}$ At the same time, the Yugoslav president said the Arabs could not be denied the right to liberate their occupied territories by means other than political, unless they felt it was impossible to act otherwise. ${ }^{19}$ In reference to the above statement, it can be assumed that in his opinion a possible next war could have led to strengthening the position of the Muslim countries, which in the long term could contribute to strengthening the importance of Yugoslavia in the Middle East and raise the country's international reputation as an intermediary between Washington and Moscow. Therefore, immediately after the outbreak of Yom Kippur War he made Yugoslavia's airspace available to the Soviet Union in order to help the Arab army, but the support was only conditional, which was inconvenient for the Kremlin. ${ }^{20}$ On the other hand, Sadat received permission to secure the flight with armament supplies from the Soviet Union over Balkan territory. $^{21}$ The Yugoslav leader even went so far in his dislike of Israel as to order Sadat to bomb Tel Aviv, which was immediately noted in Washington and met with clear bitterness as they had counted on his role as a mediator. ${ }^{22}$ Despite his support for the Arab coalition, eventually he sought to reach a settlement. The Egyptian president later wrote that Miloš Minić, the new Yugoslav minister of foreign affairs, visited Cairo on 16-17 October 1973 and tried to persuade the Egyptian side to accept a ceasefire proposal and accept his suggestion to ask the great powers for a truce. ${ }^{23}$ A month later, during Tito's visit to the USSR in November of 1973, both sides agreed that the "legal national laws" of the Palestinian refugees "had to be enforced" as part of the settlement. ${ }^{24}$ It seems that the Yugoslav president had underestimated the political and military support that the United States gave to Israel. He understood that any further continuation of the state of war between Egypt and Israel could undermine the very foundations of Yugoslavia's diplomacy, declaring peaceful cooperation between the two political blocs. We should also not forget that the authorities in Yugoslavia were afraid of a deterioration of relations with the Western coun-

${ }^{18}$ Simcha Dinitz, "The Yom Kippur War: Diplomacy of War and Peace”, in: Revisiting the Yom Kippur War, P. R. Kumaraswamy (ed.), (London-Portland: Frank Cass, 2000), 204.

19 January 18, 1973, Message from Josip Tito to Leonid Brezhnev, https://digitalarchive.wilson center.org/document/113624.pdf? $\mathrm{v}=\mathrm{ac} 1887587 \mathrm{fd} 90 \mathrm{~d} 1299 \mathrm{fc} 196553896 \mathrm{f} 6 \mathrm{e}, 3$, (accessed April $25,2020)$.

${ }^{20}$ David Andelman, "Yugoslavia: The Delicate Balance", Foreign Affairs, vol. 58, no. 4, (1980), 842.

21 Magdalena Pogońska-Pol, „Kanał do zdobycia-egipskie założenia przeprawy przez Kanał Sueski w przededniu wojny październikowej z 1973 roku", Acta Universitatis Lodziensis. Folia Historica, no. 99, (2017), 283.

22 Jože Pirjevec, Tito (Warsaw: SEDNO Academic Publishing House, 2018), 708.

${ }^{23}$ Galia Golan, Yom Kippur and After: The Soviet Union and the Middle East Crisis (London, New York, Melbourne: Cambridge University Press), 1977, 107.

${ }^{24}$ Alvin Rubinstein, Red Star on the Nile: The Soviet-Egyptian Influence Relationship Since the June War, (Princeton: Princeton University Press, 1977), 314. 
tries to such point that it would be inevitable for Belgrade to return to the Soviet bloc, which Tito wanted to avoid at all costs. In any case, the issue requires more extensive research and analysis.

The Yom Kippur War led to better relations between Yugoslavia and Egypt, which for some time where similar to those during the reign of Nasser. The authorities in Egypt, including Sadat personally, appreciated, above all, Belgrade's attempt to mediate between Egypt, the United States, and the Soviet Union, as well as Tito's readiness to defend Egypt at all costs, even if Moscow declared the final defeat of the Arab coalition in the hostilities. ${ }^{25}$ As a result, during their conversation in March of 1974, Sadat thanked Tito Yugoslavia's activity in the Non-Aligned Movement and confirmed the agreement of views between them on subjects concerning international politics ${ }^{26}$. At the same time, along with Sadat gradually opening up to an agreement with the United States and an improvement of relations with Israel, as with growing internal issues in Yugoslavia, relations gradually cooled down. Despite this, Sadat continued to treat Tito as an intermediary between him and the USSR, as evidenced by a letter from the Egyptian head of state to Brezhnev in November of 1976, which Tito forwarded to the Soviet leadership during his visit to Moscow. In his letter, Sadat declared his willingness to improve Moscow-Cairo relations, which had been exacerbated by the Egyptian Government's decision in March of that year to break the friendship and cooperation treaty. However, he set the condition that the Kremlin should respect the sovereignty and independence in its foreign policy with Egypt. ${ }^{27}$ Taking into account the USSR's unwillingness to fulfill this demand, Tito's mission ended in failure.

The Yom Kippur War resulted in the further deterioration of relations between Yugoslavia and Israel. Although Tito never denied the existence of Israel, since the end of the Six-Day War both entities had not maintained diplomatic contacts. For him, it was much more vital to support the Arab countries, which were considered to be more important for Yugoslavia's foreign policy strategy. Even during Nixon's visit to Belgrade in September of 1970, Tito was very critical of Israel's policy of maintaining the occupied territories, believing that in such state of affairs the path to a peaceful solution to the conflict was a dead end. The Yugoslav president said that if the United States was really interested in peace in the region, it had to put more pressure on Israel to make the government's policy in Tel Aviv more realistic and flexible. $^{28}$ Tito's attitude was unchanged in the ensuing years. Despite the distrust

\footnotetext{
${ }^{25}$ A. Sadat, op. cit., 14.

${ }^{26}$ Malcolm W. Browne, Sadat and Tito End Their Talks, https://www.nytimes.com/1974/03/31/ archives/sadat-and-tito-end-their-talks-egyptian-dismisses-reports-of-rift.html, (accessed April 13, 2020).

27 Sadat Said to Ask Normal Ties With Soviet, https://www.nytimes.com/1976/11/28/archives/ sadat-said-to-ask-normal-ties-with-soviet.html, (accessed April 14, 2020).

${ }^{28}$ September 30, 1970, Report on the Conversation Between Yugoslav President Josip Tito and US President Richard Nixon in Belgrade, https://digitalarchive.wilsoncenter.org/document/

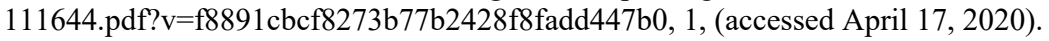


expressed by the Israeli authorities, he still enjoyed some respect among the Jews, as exemplified by his meeting in June of 1974 with Nahum Goldmann, co-founder and president of the World Jewish Congress. During the talks, the Jewish activist admitted that Tito was right about Israel's inability to pursue a power policy in international relations. Goldmann even postulated that Tito should become a mediator between Israel and the Arab countries due to his "prestige, objectivity, far-sightedness and principality". ${ }^{29}$ However, this never happened not only due to Washington's objection but also because of the more favorable attitude of the League of Communists of Yugoslavia toward Moscow. In a letter to Nixon's successor, Gerald Ford in August of 1974, he emphasized that after the retreat of the Israeli army from the Sinai Peninsula and the Golan Heights, no progress had been made toward a "peaceful and just" resolution. According to Tito, Israel was continuing to pursue a policy of aggressive action against the Arab countries and societies, mobilizing its armed forces and openly threatening its opponents. The Yugoslav president also noted that Israel was continuing to ignore the national rights of the Palestinians and prevent the participation of their legitimate representatives in overcoming the difficulties in the Middle East. In conclusion, he wrote that such a development was leading to an even greater aggravation of the crisis, which could threaten world peace and security. ${ }^{30} \mathrm{~A}$ few months later, in a conversation with Kissinger in November of 1974, Tito repeated his position on Israel, criticizing the US authorities who, in his opinion, relativized TelAviv's culpability for escalating the conflict in the Arab world. ${ }^{31}$ What is interesting, Kissinger agreed with Tito that the lack of a resolution of the dispute could lead to a further escalation of violence. ${ }^{32}$

Tito's sympathetic attitude toward the Arabs was also evident during his meeting with President Ford, who visited Belgrade in August of 1975. Although the tone of the discussion was generally positive, Tito reiterated his support for the Arabs, arguing that it was in Yugoslavia's best interests to support their independence from the Soviet Union. During the talks with President Ford, he also said that Israel was primarily responsible for prolonging the state of affairs in the region because the Jewish state did not comply with UN Resolutions 242 and 338. ${ }^{33}$ During the meeting, Tito was resentful and said that he had counted on the effectiveness of the efforts of the head of the State Department to resolve the conflict but that the situation had reached an impasse. "We think Israel

\footnotetext{
${ }^{29}$ J. Pirjevec, op. cit., 708-709.

30 August 21, 1974, Message of President Josip Broz Tito to President Ford, https:// www.fordlibrarymuseum.gov/library/document/0351/1555874.pdf, s. 29-30, 2-3, (accessed April 29, 2020).

${ }^{31}$ Tatjana Milošević, „Jugoslavija i Sjedinjene Američke Države u vreme detanta: susreti Josipa Broza Tita i Henrija Kisindžera 1970. i 1974”, Istorija 20. veka, br. 2, (2018), 200.

32 Dragan Bogetić, Jugoslovensko-američki odnosi u vreme bipolarnog detanta 1972-1975 (Beograd: Institut za savremenu istoriju, 2015), 164.

33 Belgrade, 4 August 1975, Memorandum of Conversation, https://2001-2009.state.gov/docu ments/organization/108026.pdf, s. 4., (accessed April 22, 2020).
} 
should not do what it wants" - he concluded. ${ }^{34}$ In his opinion, Israel had to relinquish the occupied Arab territories and recognize Palestinian independence if it wanted to secure its own independence and future based on peaceful cooperation with the Arab nations and countries. ${ }^{35}$ It is reasonable to believe that the Belgrade Government's reluctant position toward Israel was reinforced by the announcement of the "Sonnenfeldt Doctrine", which called for Moscow's increasing control over Eastern Europe in order to prevent World War III. What is important for Yugoslavia, Sonnenfeldt, who had close ties to the authorities in Tel Aviv, recognized Yugoslavia as being part of the Soviet Bloc, which was met with disbelief and disappointment in Belgrade. ${ }^{36}$ The disapproving attitude of the Yugoslav authorities toward Washington and its allies was also compounded by the US rejection of Belgrade's proposal to include the "Mediterranean component" into the discussion on the Conference on Security and Cooperation in Europe. By showing initiative in this matter, the Yugoslav side argued that it was difficult to achieve security in Europe if conflicts remained unresolved, for example in the Middle East. ${ }^{37}$ The unfriendly attitude of American politicians toward Yugoslavia's initiatives caused Belgrade's international position to gradually weaken.

\section{The Second Half of the 1970s and the Decline of Yugoslavia's Role in the Middle East: Belgrade's Attitude Toward the Camp David Accords}

In the second half of the 1970s, it was becoming more and more clear that Tito was losing his role as intermediary between Moscow and Washington, which had a significant impact on Yugoslavia's relations with the Middle East. In its foreign policy, Belgrade neglected the European continent, believing that the potential of national liberation movements in the Middle East could in the future threaten the hegemony of the United States, the Soviet Union, and Western Europe. In the era of colonialism and the involvement of superpowers in numerous Middle East social and political problems, he felt that it was in this space - and not in Europe - that the fate of the world would be decided. His opinion was confirmed, among others, by Stane Dolanc, one of the most influential figures in Yugoslavia's political system. In his opinion, non-alignment as a foreign policy direction was considered a political movement. He argued that there were extraordinary chances that such a policy would include not only Africa, Asia, but perhaps also Latin America. In this situation, the Movement could be accepted as an alternative to the existing constellation of international relations. ${ }^{38}$

34 Belgrade, August 4, 1975, Memorandum of Conversation, 9:50-11:30 a.m, https://history. state.gov/historicaldocuments/frus1969-76ve15p1/d74, (accessed April 23, 2020).

${ }^{35}$ J. Mocnik, op. cit.,138-139.

${ }^{36}$ Duncan Wilson, Tito's Yugoslavia (New York: Cambridge University Press, 1979), 230.

${ }^{37}$ Dragan Bogetić, ,Jugoslovenski nastup na Konferenciji o Evropskoj bezbednosti i saradnji u Helsinkiju 1973-1975", Istorija 20. veka, br. 2, (2016), 148.

38 Tvrtko Jakovina, Yugoslavia on the International Scene: The Active Coexistence of NonAligned Yugoslavia, https://yuhistorija.com/int_relations_txt01.html, (accessed April 13, 2020). 
However, both Tito and Dolanc did not understand that in the era of détente and significant world domination of both superpowers that controlled the situation in the countries of the Movement, his activity was less and less effective. Although Tito still remained an intermediary on the international arena, among others, in the dispute between Iraq and Iran in $1975,{ }^{39}$ not only Yugoslavia's internal troubles, but also the violation of human rights by the regime and the persecution of political prisoners were noticed more often than before. While the Nixon and Ford administrations did not pay attention to the question of respecting freedom of speech, the Carter Administration raised with Yugoslav officials the issue of violating human rights in the country they ruled. This pertained to the US desire for the communist bloc to respect the commitments signed on August 1, 1975, as declared at the CSCE in Helsinki. In order to win concessions from Belgrade, Vice President Walter Mondale visited Yugoslavia on 20-21 May 1977. Although the declared purpose of the trip was to "emphasize to President Tito the importance that the Carter's Administration attached to the political independence, unity and integrity of Yugoslavia", his journey was intended to attempt to force the Belgrade Government to respect human rights and implement the long-promised amnesty for political prisoners. ${ }^{40}$

Another issue contributing to the gradual decline of Yugoslavia's importance in the Middle East was Tito's failing health and concerns about the country's future after his passing. We should consider the conversation between then US Secretary of State Cyrus Vance and President Sadat as noteworthy in this sense. During their conversation, Vance asked Sadat about the prospects of the situation in Yugoslavia after Tito. He replied that he was very worried about the possible lack of stability in this Balkan country and that its situation could be very difficult. ${ }^{41}$ In the middle of the decade, discrepancies also emerged regarding Yugoslavia's economic relations with the Arab countries, as exemplified by contacts with Iraq. Both countries traditionally maintained good political relations, but economic cooperation had left much to be desired. According to Radmilo Trojanović, although relations between the two countries could be considered traditionally good and Yugoslav firms were trying to gain greater influence in Iraq, the development of mutual cooperation still lagged behind the needs expressed by both sides. ${ }^{42}$ Concerns over the country's economic future and the situation as it related to nationality meant that over the years Tito had been increasingly prone to flattery by Third World dictators, including those of the Middle East, who saw him as a defender of their interests and a supporter of their authoritarian political system. It is not without reason that one of his collaborators, Stane Kavčič, wrote that Yugo-

\footnotetext{
${ }^{39}$ J. Pirjevec, op. cit., 777.

40 J. Mocnik, op. cit., 194.

41 Washington, April 4, 1977, 1-2:45 p.m, Memorandum of Conversation, https://history.state. gov/historicaldocuments/frus1977-80v08/d26, (accessed April 16, 2020).

${ }^{42}$ Middle East, the Strategic Hub: A Bibliographic Survey of Literature (Washington: Department of The Army, 1978), 94.
} 
slavia's foreign policy saw an ally in every Arab sheikh, black leader, or Asian despot rather than in Western European countries. This policy included Stalinist suspicion, sectarianism, and Asian mentality. ${ }^{43}$

For Tito, Sadat's unexpected visit to Israel in November of 1977 and his signing of a peace treaty with Israeli Prime Minister Menachem Begin in Camp David was a chance to improve his position in the Middle East again. On one hand, the Yugoslav president welcomed the meeting of the two Arab leaders, as this legitimized his policy of easing tensions on the international stage. On the other hand, Tito treated Sadat's visit to Israel as a violation of his solidarity with other Arab countries in the fight against Israel. It is symptomatic that after Sadat left Israel, Yugoslavia, along with the GDR and Hungary, threatened to end its support to Cairo if Egypt signed a peace agreement with Israel. ${ }^{44}$ The measure of Tito's weakening position in the Middle East region was that Sadat asked Romanian dictator Nicolae Ceausescu for mediation, despite the fact that the Yugoslav president enjoyed a much better position in the Arab world than his Romanian counterpart. The then Egyptian foreign minister mentioned that after Tito had sent a letter to Sadat on 29 January 1978, pointing out the "harm" caused to the Arab camp and the rigidness of the Israeli attitude in the Middle East conflict, Sadat would reply that Tito was jealous because the Egyptian authorities had asked Ceausescu for mediation, and not him. ${ }^{45}$

Tito's reserved position on the negotiations between Egypt and Israel was also a result of his dislike for the right-wing Likud party that had ruled in Israel since 1977. Tito reasoned that the new government in Tel Aviv would not want to reach a comprehensive agreement with the Arab side. He even stated that the Geneva Conference of November 1977, aimed at restoring peace in the region, should not be convened due to the rhetoric of Likud representatives and possible opposition by Arab countries, especially Egypt. He pointed out that although Sadat was trying to appease the Israeli side, he could have considerable difficulties in controlling the opposition to the agreement with Israel among his own citizens and colleagues. In his approach, only the United States had the right instruments to maintain peace in the region and could stop any radical action by the new Israeli Government. ${ }^{46}$ Despite doubts regarding the effectiveness of the arrangements between Tel Aviv and Cairo, Tito and his colleagues in the following months of 1978 expressed the view that the talks of both parties could contribute to a breakthrough. It is interesting to point out his view, expressed during a meeting with Carter in the United States in 1978. At President Carter's remark that Sadat's visit had contributed to progress in the developments in the Middle East, Tito criticized Sadat for not consulting the Arab coun-

${ }^{43}$ J. Pirjevec, op. cit., 710-711.

${ }^{44}$ Mohammed Rahman Salameh, "The Camp David Accords: Lessons and Facts", The Arab Journal for Arts, vol. 9, no. 2A, (2012), 44.

${ }^{45}$ Muhammad Ibrahim Kamel, Camp David Accords. A testimony by Sadat's Foreign minister (London: John Wiley \& Sons, 1986), 100.

46 Belgrade, May 21, 1977, 11 a.m, Memorandum of Conversation, https://history.state. gov/historicaldocuments/frus1977-80v20/d236 (accessed May 2, 2020). 
tries about the basis for his talks with Israeli politicians. On the other hand, Tito assumed that his trip could contribute to finding a solution to the crisis in the Middle East. ${ }^{47}$ On 19 September 1978, the Yugoslav press agency, Tanjug, noted that the success of the negotiations in Camp David had exceeded all expectations and the peace agreement should be considered as an important step to overcome the difficulties in the Middle East once and for all. ${ }^{48}$

Despite Belgrade's official satisfaction with the favorable resolution of the dispute, Egypt's rapprochement with the United States meant the failure of Tito's independent policy and contributed to increased criticism against him among Arab states opposed to the agreement. Therefore, during his visit to Moscow in May of 1979, the Yugoslav leader emphasized that if most Middle East countries opted for the exclusion of Cairo from the Non-Aligned Movement, then he does not see any contraindications for this. ${ }^{49}$

It can be assumed that the Yugoslav side tried to use the IsraeliEgyptian agreement also to mediate in the dialogue between Israel and the Palestinians. Hoping for a peace arrangement analogous to Camp David, the Belgrade authorities tried to present to the Western countries the need to enter into talks with the PLO. In talks with the Washington Administration, Tito's close associate, Edvard Kardelj considered the issue of Palestinian status to be the main cause of the dispute in the region. Kardelj maintained that despite their radicalism toward Israel, they were prepared to change their policy but wanted in return political rights in Yugoslavia to be guaranteed by the Western countries. ${ }^{50}$ According to Kardelj, although it was difficult to say how mutual relations could be regulated, if it was possible to sign a long-term agreement, it would even be possible to create an independent Palestinian state. In return, the Palestinians would be prepared to recognize Israel, provided they had access to the Mediterranean Sea. Kardelj also noted that in the comprehensive implementation of a possible peace plan for the Middle East it would be important to include the PLO as an international entity and have all the Arab states recognize the PLO as the representative of the Palestinian nation. $^{51}$ Nevertheless, such ideas were impossible at that time because of the radicalism of the Palestinian side and its reluctance to agree to any talks with Israel, and also because of the financial and logistical support of Palestinian terrorism by a number of Soviet Bloc countries, specifically the USSR, East Germany, and Romania. The desire to take advantage of the situation by the

47 Editorial Note, https://history.state.gov/historicaldocuments/frus1977-80v20/d253, (accessed May 5, 2020).

48 Assessment of the 1978 Middle East Camp David Agreements (Washington: U.S Government Printing Office, 1978), 80.

49 Видосава Ераковић, „'Нека ђаво носи Запад, важно је шта ми о томе говоримо' последња посета Јосипа Броза Тита Москви (17 - 18. мај 1979)“, Архив, часопис Архива Југославије, бр. 1-2, (2014), 190.

50 Washington, September 30, 1977, 10:40-11:25 a.m., Memorandum of Conversation, https:// history.state.gov/historicaldocuments/frus1977-80v20/d244, (accessed April 13, 2020).

${ }^{51}$ Ibid. 
Eastern Bloc was visible, for example, in Iran. The events that took place there in late 1978 and early 1979 were a serious problem for Yugoslavia, which had been embroiled in an ethnic crisis in the late 1970s.

\section{Yugoslavia and the Islamic Revolution in Iran}

The last point to consider in this text is Yugoslavia's position toward the Islamic Revolution in Iran. This was an important development for Tito, not only because of the geopolitical disturbance that it triggered, but also due to its importance for the Yugoslav Muslims, one of Yugoslavia's constitutive nations. Throughout the 1970s, Tito actively supported Shah Reza Pahlavi, sincerely believing that as long as the Shah ruled, Iran would not seek to export radical Islamic ideology to Yugoslavia. The rapprochement of those two countries and their leaders was also influenced by their joint experiences in the early $1950 \mathrm{~s}$, when they decided to pursue a policy independent of Moscow. During one of his meetings with Tito, Pahlavi said that Yugoslavia, together with Iran, was the only country able to oppose the Soviet regime. He emphasized that Tito had accomplished an extraordinary task, uniting all of Yugoslavia's ethnic groups and modernizing the country. The Shah expressed his hope that whoever succeeded the Yugoslavian leader would maintain his political course. ${ }^{52}$

The Islamic Revolution changed the situation in Iran. It can be hypothesized that the president of Yugoslavia viewed the Shah's abdication with concern for several reasons. In the face of ethnic and nationality problems in Yugoslavia, he was afraid of the rise of Islamic fundamentalism. He realized that fundamentalists, observing the events in Iran, would like to reproduce the model of Iranian theocracy on Yugoslav soil. This was confirmed by Michał Zacharias, according to whom the development of this trend and the Iranian Revolution were met with praise by the Muslim inhabitants of Yugoslavia. ${ }^{53}$ One of the examples can be the growing influence of Iran in Bosnia and Croatia, present since 1979, although formally only during the war in the Former Yugoslavia, Tehran strengthened its position there. ${ }^{54}$ Being aware of the threats to the national cohesion of Yugoslavia, from the beginning of 1979, Tito sought to strengthen control and restore the disturbed balance in order to strengthen the Muslims against the greater strength of the Serbs but did not want them to play too important a role in Yugoslav society. In a short time, he issued warnings to several Muslim leaders, including the Belgrade Mufti for allegedly attempting to disturb the atmosphere of "brotherhood and unity" among the multinational inhabitants of Yugoslavia. Fuad Muhić, one of the main theoreticians of com-

\footnotetext{
52 Mohammad Reza Pahlavi, Answer to History (New York: Stein and Day, 1980), 132.

53 Michał Zacharias, „Ustrój Jugosławii w latach 1974-1980. Przesłanki dezintegracji i późniejszego rozpadu państwa”, Studia z Dziejów Rosji i Europy Środkowo-Wschodniej, no. 36, (2001), 177-178.

54 Matteo Pugilese, "Iran in the Bałkans", Limes - Italian Journal of Geopolitics, https:// pdfslide.net/documents/iran-in-the-balkans-intelligence-and-in-iran-in-the-balkans-matteopugliese.html, 2, (accessed April 28, 2020).
} 
munism in the League of Communists of Yugoslavia, even accused the representatives of Muslim communities in Yugoslavia, without mentioning their names, of succumbing to the influences of Khomeini's ideology. In an interview to the Start weekly magazine, he said that no matter how important it was for Iran, such "revolutionary Islamic socialism" would not happen in Yugoslavia. 55 Shortly afterward, during a visit to Bosnia, dominated by followers of Islam, Tito praised the officials of that federal republic for taking tough action against "subversive activities of the clergy." In his opinion, such attempts to "undermine brotherhood and unity" had to be nipped in the bud, despite criticism of repression coming from outside the borders of Yugoslavia. ${ }^{56}$

Another reason why Tito was shocked by the events in Iran was the fact that Iran's new spiritual leader was the first Arab politician to challenge the Yugoslav president's leadership in the Non-Aligned Movement and in the Middle East. Khomeini accused Tito of repressing Muslims through "corruption and a revolver", 57 which was a problem for his long-standing policy of defending Muslim interests before the United States, the Soviet Union, and Israel. The religious upheaval in Iran undermined Tito's policy in non-aligned countries, because the countries belonging to the Movement had favored a more secular model of Islam. Hoping that the Movement would weaken the activities of the fundamentalists, Tito sought to ensure that the Muslims in Yugoslavia would follow the communist doctrine, but on the other hand, he did not want to persecute them because of their origin. ${ }^{58}$ The Iranian ayatollah underestimated Belgrade's previously expressed support for Islam, rightly believing that the Yugoslavian leader was not in favor of the expansion of the Muslim religion and the theocratic system of exercising power that could threaten his rule in Yugoslavia. Seeing all unorthodox followers of the Islamic religion as enemies, Khomeini assumed that only violent repression could increase the influence of the theocrats. Tito expressed his concern over the fate of moderate Islamists in Iran in a conversation with Cuban leader Fidel Castro at the Non-Aligned summit in Havana in August of 1979. He said then that the situation in the Middle East was very difficult, because, among other things, of the repression of the new regime against the Kurds. The Yugoslav president pointed out that the predictions for the future were not optimistic, because apart from Tehran's problems in relations with other countries, there were also unresolved religious issues. He blamed Khomeini's inflexibility for the above state of affairs. ${ }^{59}$ Another factor contributing to tension between Tehran and Belgrade was the Yugoslavia's lack of support to Iran for the imprisonment of American hostages in the Iranian

\footnotetext{
${ }^{55}$ Michael Doobs, Tito Acts to Halt Spread of Pan-Islamic Ideology, https://www.washington post.com/archive/politics/1979/12/06/tito-acts-to-halt-spread-of-pan-islamicideology/3975c902-71d2-4236-b0f4-8c5a91a03042/ (accessed April 29, 2020).

${ }^{56} \mathrm{Ibid}$.

${ }^{57}$ Nora Beloff, Tito's Flawed Legacy. Yugoslavia and the West 1939-1984 (London: Westview Press, 1985), 216.

58 Jasper Ridley, Tito: A Biography (London: Constable \& Robinson Ltd, 1996), 400.

${ }^{59}$ V. Petrović, op. cit., 300.
} 
capital in November of 1979. Therefore, at the end of that year, relations between the two countries left much to be desired. However, for Yugoslavia, relations with Iran lost their importance in late 1979 and early 1980 after the Soviet Army entered Afghanistan, triggering another global crisis. Soon thereafter Tito died, closing an important chapter of Yugoslav foreign policy and its Middle Eastern component.

\section{Conclusion}

To recapitulate these considerations, we must state that in the 1970 s the Middle East played a significant role in Yugoslavia's foreign policy. Throughout the decade of international relaxation, diplomats in Belgrade had perceived Yugoslavia's activity in the Arab world as a means of increasing this Balkan country's international significance and weakening the pressure of the United States and the Soviet Union on Yugoslavia. The involvement in the Arab-Israeli conflict turned out to be unavoidable for the Yugoslav head of state, as some Arab countries were members of the Non-Aligned Movement. However, along with his health problems, the complex internal situation of Yugoslavia, and changes on the international arena, his position as one of the main figures in world politics was depreciating. It was clear that in the face of an immediate threat, Belgrade could no longer pursue its policy of balancing between the two blocs, which had an impact on Yugoslavia's policy in the Middle East. The Islamic Revolution in Iran, the Soviet intervention in Afghanistan, and the deteriorating economic situation made the rulers aware that despite their orthodox communist beliefs, only closer cooperation with the West would help them protect the country's sovereignty and thus contribute to keeping them in power. Therefore, in the next decade Yugoslavia's contacts with the United States and the Western countries improved, while limiting Yugoslavia's activity in the Third World, including the Middle East. 


\section{REFERENCES}

- Andelman, David. "Yugoslavia: The Delicate Balance". Foreign Affairs, vol. 58, no. 4, (1980), 835-851. https://doi.org/10.2307/20040506

- Assessment of the 1978 Middle East Camp David Agreements. Washington: U.S Government Printing Office, 1978.

- Beloff, Nora. Tito's Flawed Legacy. Yugoslavia and the West 1939-1984. London: Westview Press, 1985.

- Bernaś, Franciszek. Mrok i mgła. Z dziejów KGB. Warszawa: ETNOS, 1997.

- Bogetić, Dragan. Jugoslovensko-američki odnosi u vreme bipolarnog detanta 1972-1975. Beograd: Zavod za udžbenike, Institut za savremenu istoriju, 2015.

- Bogetić, Dragan. „Jugoslovenski nastup na Konferenciji o evropskoj bezbednosti i saradnji u Helsinkiju 1973-1975“. Istorija 20. veka, br. 2, (2016), 137-164. https://doi.org/10.29362/IST20VEKA.2016.2.BOG.137-164

- Browne, Malcolm W. Sadat and Tito end their Talks, https://www.nytimes. com/1974/03/31/archives/sadat-and-tito-end-their-talks-egyptian-dismissesreports-of-rift.html (accessed April 13, 2020).

- Kamel, Muhammad Ibrahim. Camp David Accords. A testimony by Sadat's Foreign Minister. London: John Wiley \& Sons, 1985.

- Dinitz, Simcha. "The Yom Kippur War: Diplomacy of War and Peace". In: Revisiting the Yom Kippur War, Kumaraswamy P. R. (ed.). London-Portland: Frank Cass, 2000. https://doi.org/10.1080/13537129908719548

- Doobs, Michael. Tito Acts to Halt Spread of Pan-Islamic Ideology, https://www.washingtonpost.com/archive/politics/1979/12/06/tito-acts-to-haltspread-of-pan-islamic-ideology/3975c902-71d2-4236-b0f4-8c5a91a03042/ (accessed April 29, 2020).

- Eraković, Vidosava. „'Neka đavo nosi Zapad, važno je šta mi o tome govorimo' - poslednja poseta Josipa Broza Tita Moskvi (17 - 18. maj 1979)". Arhiv, časopis Arhiva Jugoslavije, br. 1-2, (2014), 182-193.

- Golan, Galia. Yom Kippur and After: The Soviet Union and the Middle East Crisis. London, New York, Melbourne: Cambridge University Press, 1977.

- Jakovina, Tvrtko. Yugoslavia on the International Scene: The Active Coexistence of Non-Aligned Yugoslavia, https://yuhistorija.com/int_relations_txt01. html (accessed April 13, 2020).

- Lebl, Aleksandar. „Prekid diplomatskih odnosa SFRJ - Izrael 1967. godine“. Tokovi istorije, br. 1-4, (2001), 39-75.

- Middle East, the Strategic Hub: A Bibliographic Survey of Literature. Washington: Department of the Army, 1978.

- Milošević, Tatjana. „Jugoslavija i Sjedinjene Američke Države u vreme detanta: susreti Josipa Broza Tita i Henrija Kisindžera 1970. i 1974“. Istorija 20. veka, br. 2, (2018), 187-202. https://doi.org/10.29362/ist20veka.2018.2.mil.187-202

- Mocnik, Josip. United States-Yugoslav Relations, 1961-80: The Twilight of Tito's Era and the Role of Ambassadorial Diplomacy in the Making of Ameri- 
ca's Yugoslav Policy, Ohio 2008. https://etd.ohiolink.edu/!etd.send_file\% 3Faccession\%3Dbgsu1206322169\%26disposition\%3Dinline, (accessed 16 April, 2020).

- Pahlavi, Mohammad Reza. Answer to History. New York: Stein and Day, 1980.

- Petrović, Vladimir. Titova lična diplomatija. Studije i dokumentarni prilozi. Beograd: Institut za savremenu istoriju, 2010.

- Pogońska-Pol, Magdalena. „Kanał do zdobycia- egipskie założenia przeprawy przez Kanał Sueski w przededniu wojny październikowej z 1973 roku”. Acta Universitatis Lodziensis. Folia Historica, no. 99, (2017), 277-290. https://doi.org/10.18778/0208-6050.99.14

- Pirjevec, Jože. Tito. Warsaw: Wydawnictwo Sedno, 2018.

- Pugilese, Matteo. "Iran in the Bałkans". Limes - Italian Journal of Geopolitics https://pdfslide.net/documents/iran-in-the-balkans-intelligence-and-in-iran-inthe-balkans-matteo-pugliese.html, (accessed April 28, 2020).

- Ridley, Jasper. Tito: A Biography. London: Constable \& Robinson Ltd, 1996.

- Rubinstein, Alvin. Red Star on the Nile: The Soviet-Egyptian Influence Relationship Since the June War. Princeton: Princeton University Press, 1977.

- Rubinstein, Alvin. "The Evolution of Yugoslavia's Mediterranean Policy". International Journal, vol. 27, no. 4, (1972), 528-545. https://doi.org/10.1177/ 002070207202700403

- Sadat, Anwar. Nasser's Death and My Relations with Tito, https://anwarsadat. org/site/project_img/book/4889.pdf, (accessed April 11, 2020).

- Sadat Said to Ask Normal Ties With Soviet, https://www.nytimes.com/1976/ 11/28/archives/sadat-said-to-ask-normal-ties-with-soviet.html, (accessed April 14, 2020).

- Salameh, Mohammed Rahman. "The Camp David Accords: Lessons and Facts". The Arab Journal for Arts, vol. 9, no. 2A, (2012).

- Wilson, Duncan. Tito's Yugoslavia. New York: Cambridge University Press, 1979.

- Zacharias, Michał. Komunizm, federacja, nacjonalizmy. System wtadzy w Jugostawii $w$ latach 1943-1991. Warszawa: Instytut Historii PAN, Wydawnictwo Neriton, 2004.

-Zacharias, Michał. „Ustrój Jugosławii w latach 1974-1980. Przesłanki dezintegracji i późniejszego rozpadu państwa". Studia z Dziejów Rosji i Europy Środkowo-Wschodniej, no. 36, (2001), 159-187. 
PAWEŁ BIELICKI, PhD, Scholar

Pilecki Institute

Warsaw, Republic of Poland

bielicki11@gmail.com

\author{
THE MIDDLE EAST IN YUGOSLAVIA'S \\ FOREIGN POLICY STRATEGY IN THE 1970s
}

\begin{abstract}
Summary
The main purpose of this article is to present the most important conditions and variables characterizing the role of the Middle East in Yugoslavia's foreign policy strategy in the 1970s, based on available literature and documentation. I also intend to analyze the conditions that contributed to intensifying Yugoslavia's position in the region and led to a decrease in Yugoslavia's importance in the Middle East in the second half of the decade. Firstly, I will describe Yugoslavia's relations with the countries of the Middle East in 19701973, especially with Egypt, where Gamal Abdel Nasser, after his death, was succeeded by the country's Vice President, Anwar Al-Sadat. It will also be important to shed light on the Yugoslav Government's stance regarding the Middle East conflict from the point of view of the situation in Europe. Next, I will present the significance of the Yom Kippur War for Yugoslavia's foreign policy and its implications for Belgrade's relations with Cairo and Tel-Aviv. Moreover, it will be extremely important to explain why Yugoslavia's importance in the Middle East gradually diminished as of the middle of the decade. In addition, I will address the issue of Yugoslav President Josip Broz-Tito's position toward the Islamic Revolution in Iran and the fading of Yugoslavia's interest in the region following Tito's death and the Soviet invasion of Afghanistan. In the summary, I want to note that the period under analysis in Yugoslav-Middle Eastern relations was decisive for the country's foreign policy and its internal situation, as Yugoslavia never again played a significant role in the Arab world.
\end{abstract}

KEYWORDS: Middle East, Egypt, Israel, Yugoslavia, USSR, United States 